\title{
The environmental legacy of the Ixtoc-I oil spill in Campeche Sound, southwestern Gulf of Mexico
}

\author{
Luis A. Soto ${ }^{1 *}$, Alfonso V. Botello ${ }^{1}$, Sergio Licea-Durán ${ }^{1}$, Marcial L. Lizárraga-Partida ${ }^{2}$ and \\ Alejandro Yáñez-Arancibia ${ }^{3}$ \\ Instituto de Ciencias del Mar y Limnología, Universidad Nacional Autónoma de México, Unidad Académica de Procesos Oceánicos y Costeros, Ciudad \\ Universitaria, México, D.F., México \\ ${ }^{2}$ Centro de Investigación Científica y de Educación Superior de Ensenada, Ensenada, Mexico \\ ${ }^{3}$ Instituto de Ecología A.C., INECOL (CONACYT), Red Ambiente y Sustentabilidad, Unidad Ecosistemas Costeros, Xalapa, México
}

\section{Edited by:}

Alex Ford, University of Portsmouth, UK

\section{Reviewed by:}

Antonio Olita, National Research Council - Institute for Coastal Marine Environment, Italy John William Farrington, Woods Hole Oceanographic Institution, USA

\section{*Correspondence}

Luis A. Soto, Instituto de Ciencias del Mar y Limnología, Universidad Nacional Autónoma de México, Unidad Académica de Procesos Oceánicos y Costeros, Ciudad Universitaria, México, D.F. 04510 México

e-mail: lasg@cmarl.unam.mx
The southwestern Gulf of Mexico constitutes an important subsystem within a Large Marine Ecosystem. Due to its high biodiversity, living resources and energy resources, this region is strategic in the national plans for social and economic development of Mexico. The discovery of fossil fuel reserves in the seabed of Campeche Sound in the 1970s promoted the rapid expansion of the national oil industry in offshore waters. Unfortunately, the accidental blowout of the most productive well (Ixtoc-I) in June of 1979, caused the first-world massive oil spill in a tropical marine environment. More than 3.4 million of barrels of crude oil were liberated in an ecosystem formerly renowned for its pristine conditions. In the aftermath of this dreadful accident, a growing concern emerged not only for the oil acute effects but also for the long-term environmental consequences derived from the residual hydrocarbon compounds accumulated in coastal environments of the southern Gulf of Mexico. The attempts to assess the magnitude of the environmental damage were strongly precluded by the lack of pre-spill information. Natural variability in the ecosystem and oil weathering-factors contributed to attenuate the acute pollution effects that lasted nearly 9 months. However, the post-spill environmental alterations caused by the Ixtoc-I blowout still remain unanswered. The sinking of the Deepwater Horizon oil platform in the deep-waters of the northern Gulf of Mexico, in 2010 rekindled our concern for the significant risk involved for human lives and the health of shallow and deep marine habitats. The authors of this contribution offer their views on this environmental riddle from their own perspective as direct witnesses of the Ixtoc-I environmental tragedy.

Keywords: oil-spill, campeche sound, hydrocarbons compounds, southwestern Gulf of Mexico, environmental assessment, fish-community

\section{ENVIRONMENTAL SETTING OF THE SW GULF OF MEXICO}

The southwestern Gulf of Mexico constitutes an important subsystem within a Large Marine Ecosystem (Sherman, 1994; Kumpf et al., 1999) represented by the entire Gulf region. This particular sector of the Gulf is oceanographically complex and dynamic. Its waters are highly influenced by the river runoff from a major tributary system (e.g., GrijalvaUsumacinta, Coatzacoalcos, Papaloapan) and the flow of nutrients and dissolved organics exported by a complex of coastal lagoons and estuaries onto the adjacent shelf environment. Geographical/hydrological units have been defined in an international context as an environmental management tool in the Gulf of Mexico (Yáñez-Arancibia and Day, 2004). Due to its high biodiversity, living resources, urban and industrial expansion and energy resources, this region has been considered strategic in the national plans for the social and economic development of Mexico.

The southwestern Gulf encompasses two major geological provinces, each with distinctive topographic features: the
Bay of Campeche and the Campeche Bank (Antoine, 1972; Figure 1). Depositional environments in the Bay of Campeche can be categorized as highly terrigenous along a progressively narrow continental shelf to the west and carbonate on the broad platform toward the Campeche Bank in the east.

The Campeche Bank extends roughly over a surface area of $129,500 \mathrm{Km}^{2}$. Its unique ecological conditions are best reflected in a rich primary productivity $\left(>40.4 \mathrm{mg} \mathrm{C} \mathrm{m}^{-2} \mathrm{~d}^{-1}\right.$ ), the presence of important coral reef systems and the activity of one of the most important industrial penaeid shrimp fisheries in the Gulf of Mexico $\left(>16,000 \mathrm{t} / \mathrm{y}^{-1}\right)$. Since the late 1970s, this marine province has also served as the primary field for major national offshore oil and gas operations with an increasing annual production of more than $1095 \times 10^{5}$ barrels. These two industries, the traditional shrimp fishery and the aggressive fossil fuel extraction activities, have coexisted on the offshore waters of the Campeche Bank under a rather conflicting atmosphere for several decades. 


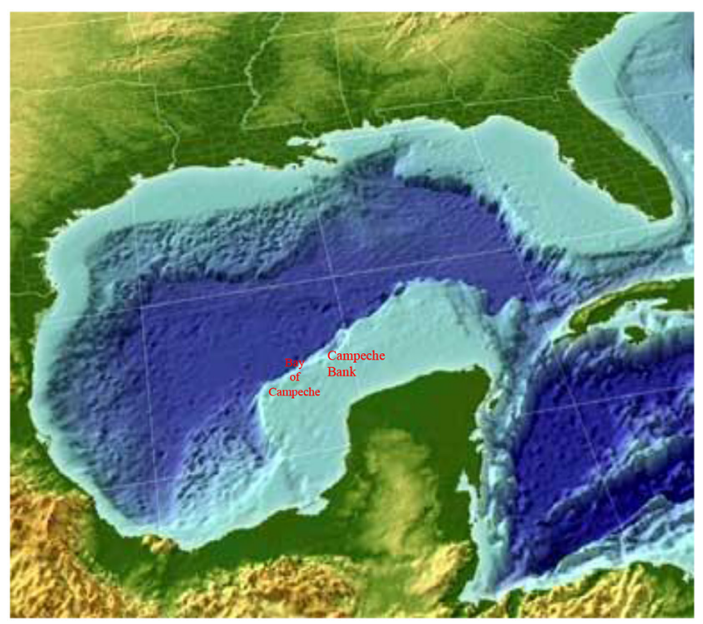

FIGURE 1 | Location of the Bay and Campeche Bank in the southwestern Gulf of Mexico (modified from Google earth).

\section{RECOUNTING THE WORLD'S FIRST MASSIVE OFFSHORE OIL SPILL}

Ever since the dreadful oil spill caused by the Ixtoc-I blowout in June 1979 in Campeche Sound, there has been a growing concern for the deleterious environmental effects upon a marine ecosystem, formerly known for its fairly pristine conditions prior to the rapid expansion of oil exploration and the extraction of fossil fuels in the area. Unfortunately, this accident was the world's first- massive oil spill occurring in offshore waters of a tropical environment. More than 3.4 millions of barrels of crude oil were liberated by the Ixtoc-I blowout into the Gulf of Mexico, for nearly 9 months (PC-EESC, 1980).

No precedent had existed before of an oil spill of such a magnitude. The accident was further aggravated by the absence of a rapid response to control and mitigate the grave pollution effects not only in oceanic waters but also on the eventual transportation of oil mousse, sheen and tar balls toward the coastal zone by the prevailing surface circulation pattern in the area. Another factor that precluded a preliminary environmental assessment of the seriousness of the ecological damages caused by the spill was the lack of pre-spill baseline information to compare it with the conditions of environmental midterm spills.

Mexican authorities were overwhelmed by the international pressure to cap the wellhead with the best technology at hand to avoid further environmental damages. Skimmers, boom lines and chemical dispersants were employed in an attempt to contain the crude oil at the surface. Drilling operations of two-relief oil wells were decided on by PEMEX's experts as a solution, given the failure to control the high-gas pressure at the Ixtoc-I's wellhead.

It took 4 months for the government authorities to organize a task force to assess the environmental damages in Campeche Sound. A multinstitutional task force was created for that purpose under the name of "Programa Coordinado de Estudios Ecológicos en la Sonda de Campeche" -Coordination Program of Ecological Studies in Campeche Sound (PC-EESC)-. The leading national research institutions in Mexico participated in implementing a short and midterm strategic observational plan to detect the environmental disturbances caused by the crude oil in the different ecosystem compartments: atmosphere, water, sediments and biota. An oil dispersal model was developed in order to predict the direction of the plume and to implement a prevention plan in potential coastal areas that could receive weathered fossil hydrocarbons from the Ixtoc-I.

As indicated earlier, the lack of knowledge on pre-spill conditions in the area of study made it difficult for the experts to distinguish, in the case of biological components, the natural variability of community parameters (e.g., biomass, diversity, abundance, and density) from that caused by anthropogenic disturbances. Most of the technical reports emanating from the field surveys conducted in Campeche Sound in the period 1979-1980 concurred that the evaporation, dispersion, photo-oxidation and biodegradation processes in this zone played a major role in attenuating the harmful environmental effects of the oil spill. For instance, 2 months after the Ixtoc-I blowout, while the oil spill was still in progress, Boehm and Fiest (1982), were able to analyse the high molecular-weight hydrocarbons in seawater employing synchronous fluorescence spectroscopy. They reported significant concentrations from $5 \mu \mathrm{g} \mathrm{L}$ to $10,600 \mu \mathrm{g} \mathrm{L}$ that exceeded those considered as critical for near shore environments affected by an oil spill $(2-100 \mu \mathrm{g} \mathrm{L})$. Interestingly, prior and after the Ixtoc-I event, Botello and Villanueva (1987) reported on the concentrations of total hydrocarbons (THC) in sediments and biota from Campeche Sound, using glass capillary gas chromatography. The baseline level for THC in sediments obtained by these authors in 1978 was close to $31 \mu \mathrm{g} \mathrm{g}^{-1}$ reaching a maximum concentration of $81 \mu \mathrm{g} \mathrm{g}^{-1}$ nearly a year after the Ixtoc-I blowout. Approximately 2 years after the accident, the THC concentration in sediments returned to background levels $(\sim 32 \mu \mathrm{g}$ $\mathrm{g}^{-1}$ ) presumably due to physical and biodegradation processes. Additionally, the tropical shelf ecosystem displayed its remarkable resilient capacity by absorbing, in time and space, the severe anthropogenic disturbance.

Even though, in the beginning, there was a consensus within the scientific community that the above weathering factors indeed diminished the acute pollution effects, numerous questions arose afterwards concerning the degradation rates and the toxicity of the residual Ixtoc-I hydrocarbons in sediments and biota. Similarly, there were no definite ideas as to the mid- and longterms post-spill environmental consequences.

In the light of this brief recounting of facts, events and decisions made at the outset of the oil-spill accident, an undeniable truth emerged from all this: in Campeche Sound there was a Biological Economy prior to this accident and a different one after the oil spill occurred. Since then, many changes have occurred in this area. PEMEX has continued expanding its inshore and offshore operations causing again chronic accidental oil spills. However, such operations are presumably being conducted under a better legal framework focused on preserving the health of the ecosystem. In spite of these actions, the fate of the coastal and marine resources in Campeche Sounds is still uncertain. The authors of this contribution, motivated by the current interest in finding out about the oil spills long-term effects in the marine ecosystem, offer their own views based on 
their experience by assessing the Ixtoc-I blowout from different perspectives.

\section{LESSON LEARNED FROM THE Ixtoc-I BLOWOUT}

Perhaps one of the earliest and most objective environmental assessments on the devastating Ixtoc-I oil spill was the report elaborated by the United Nations (UNEP) team of experts led by Arne Jernelöv (see Jernelöv and Lindén, 1981). In this report, the authors explain the general behavior of the spilled oil and give a detailed account on the clean-up operations and the efforts implemented by PEMEX to stop the flow of oil. After describing the main features of the most vulnerable coastal ecosystems in the southwestern Gulf of Mexico, the authors discussed some of the biological effects the spill theoretically have caused, supported by direct observations made in the field. These experts drew a series of important conclusions related to the total volume of crude oil released by the blowout, its fate and the weathering processes in the warm waters of the Gulf $\left(>25.0^{\circ} \mathrm{C}\right)$; but more importantly, they offered the first evaluation of the acute effects of fossil hydrocarbons upon local fisheries and coastal environments adjacent to Ixtoc-I. In their opinion, no conclusive judgment could be made on the environmental damage caused by one the world's biggest oil spill.

Later on, other authors (e.g., Botello and Castro, 1980; Soto et al., 1981; Licea et al., 1982; Yáñez-Arancibia et al., 1982; Guzman del Próo et al., 1986; Yáñez-Arancibia, 1986) added further evidence concerning the crude oil effects and their possible bioaccumulation in sediments, plankton and demersal fauna of Campeche Sound.

In 1982, the PC-EESC convened the International Symposium on the Ixtoc-I oil spill held in Mexico City in which numerous research themes were discussed. Interestingly enough, the Symposium's report included a prolog written by a PEMEX CEO, in which he categorically concluded, based on a 2-year multidisciplinary study of Campeche Sound that "...the marine ecosystem did not suffer any damage by the Ixtoc-I oil spill." With this appalling statement, it seemed as if the final chapter on the IxtocI oil spill had come to its conclusion. No intentions from the Mexican government to support a long-term research program to assess the ecological damages derived from one of the largest oil spills in history were ever expressed.

Since then, only the individual efforts of a few scientists (e.g., Yáñez-Arancibia, 1985, 1986; Lizárraga-Partida et al., 1991; Soto and Escobar-Briones, 1995; García-Cuéllar et al., 2004; Botello et al., 2005; Soto and González, 2009; Soto et al., 2009; YáñezArancibia et al., 2009, 2013a,b; Baltz and Yáñez-Arancibia, 2013), concerned with the environmental health of one of the most productive regions in the Gulf, have kept alive the need for maintaining permanent observations on stressor factors that may upset the fragile ecosystem integrity.

According to Jernelöv and Lindén (1981), a considerable percentage of the Ixtoc-I crude oil was either evaporated $(48 \%)$ or sunk to the sea floor (24\%); other oil remains were washed ashore in adjacent coastal areas (6\%), and on US beaches (3\%), 12\% was biodegraded, and $7 \%$ was burned or directly recovered at the site. Naturally, the new findings of high concentrations of total hydrocarbons in surficial sediments in both coastal and estuarine systems (Botello et al., 1991; Botello, 1996) fueled once more the controversy on the fate and toxicity of the Ixtoc-I oil spill vs. the chronic pollution caused by PEMEX's offshore operations in Campeche Sound.

In the aftermath of Ixtoc-I several revealing facts came to light: (1) tropical environments respond differently to man-produced disturbances; (2) both physical and chemical reactions are accelerated at twice their normal rate by warm ambient temperatures, biological processes having a similar metabolic response $\left(\mathrm{Q}_{10}\right)$; (3) given their rich biodiversity, tropical systems are more resilient and perhaps can recover faster from a disturbance than a temperate system; (4) biodegradation processes can also be promoted by a rich microbiota if sufficient nutrients and oxygen are present; (5) in regions such as Campeche Sound, with a high input of biogenic hydrocarbons from estuarine systems, the detection of petrogenic hydrocarbons in sediments or animal tissues can have a masking effect; (6) natural biological variability in a tropical ecosystem may impede the production of unequivocal evidence of pollution from oil offshore operations.

From a strictly environmental perspective, the Ixtoc-I blowout experience has served as an example of the imperative need to strengthen the prevention and emergency procedures of the international oil and gas operations in offshore waters. Unfortunately, the Macondo oil spill off the coast of Louisiana is a painful reminder of the great risk involved for human lives and the health of the marine ecosystem and the growing expansion of the oil explorations in fragile environments.

\section{THE Ixtoc-I OIL BLOWOUT AND THE LIVING RESOURCES OF CAMPECHE SOUND}

Historically, the fishing resources of the Gulf of Mexico have presumably been exposed to chronic oil effects for an extended period. Apparently, no significant decline has yet been detected in the production levels other than those attributed to an overexploitation (e.g., Baltz and Yáñez-Arancibia, 2013; Seijo et al., 2013). However, it is important to recognize that the fishing stocks restricted to certain spawning grounds, as in the case of penaeid shrimp from Campeche, are more vulnerable to oil exposure.

The area of Campeche is an excellent habitat that has traditionally supported the commercial exploitation of demersal resources since 1950. Many of the exploited species have a marine-estuarine dependent life-cycle. This implies that the amount of fresh water and terrigenous sediments discharged onto the continental shelf area are related to the production of finfish and shellfish in the coastal zone of the SW Gulf (Yáñez-Arancibia, 1985; YáñezArancibia and Pauly, 1986; Yáñez-Arancibia et al., 1994, 2007). Therefore, any disturbance caused in either the coastal or marine habitats can have serious repercussions on the population balance of larvae and the juvenile and adult stages.

In the late 1960s, the shrimp fishery was the best example of a flourishing fishing industry responsible for $21 \%$ of the Mexican shrimp exports with a total value of $\$ 170.7$ million (Mexican currency, 2001). In Campeche Sound there coexist three of the most important penaeid stocks exploited in the Gulf of Mexico: Farfantepenaeus aztecus (brown shrimp), F. duorarum (pink shrimp), and Litopenaeus setiferus (white shrimp). There are five other co-occurring penaeid species whose biomass 
( $<20 \%$ of the total catch) is not commercially significant (Soto et al., 1981).

The Campeche industrial shrimp fishery depends heavily on the exploitation of pink shrimp, whereas white shrimp support the artisanal fishery in inshore waters and brown shrimp are captured mainly off the waters of Tampico and Texas. The Campeche shrimp fishery corresponds to a sequential modality in which there are two components: the industrial or marine and the artisanal or coastal/estuarine; both components are closely intertwined to the point that any negative factor affecting one produces the same effect on the other.

Despite this, the shrimp fishery in the Gulf of Mexico, profusely studied and regulated (Díaz de León et al., 2004), is far from reaching sustainable levels. In the opinion of fishery scientist, the overexploitation and excessive fishing effort are the main adverse factors that explain its declining production. In contrast, other scientists (e.g., Hernández et al., 2003; Villalobos-Zapata, 2010) have explicitly stated that the shrimp production collapse and the coastal damages in the Campeche Sound are directly attributed to PEMEX's operation in this area.

\section{BACTERIAL RESPONSE TO OIL INPUTS}

In the marine environment, hydrocarbonoclastic bacteria (HCB) respond rapidly to oil input by increasing their predominance over heterotrophic microorganisms and also over total bacterial counts. Thus, a high percentage of crude-oil degraders correspond to high concentrations of total hydrocarbons (LizárragaPartida et al., 1982). The waters in the SW Gulf of Mexico, as indicated earlier, are highly influenced by the river runoff from a major tributary system: Grijalva-Usumacinta-CoatzacoalcosPapaloapan. Within this tributary system, the coastal lagoon of Términos exhibits a clear seasonal increase in the concentration of oil degraders in surface sediments and water during the rainy season; such an increase is related to the oil residues discharged from inland sources (Lizárraga-Partida, 1996). This river runoff represents a chronic input of hydrocarbons in Campeche Sound and has a seeding effect of HCB in this area. The offshore oil platforms are also a source of chronic and accidental hydrocarbon input. From 1984 to 1985, Lizárraga-Partida et al. (1991) who sampled water and sediment from Campeche Sound, in the proximity of several oil platforms, including the Ixtoc- I. Oil platforms in operations, showed drastic fluctuations of oil degrader percentages in surface waters and sediments with no clear seasonal pattern. No significant changes in the percentage of oil degraders were detected near the Arcas Reef's oil-tanker loading zone. On the shelf of Campeche Sound, the high percentage of oil degraders corresponded to areas directly exposed to river plumes. However, offshore waters and sediments adjacent to oil rigs exhibited the highest percentages, thus emphasizing their vital role as the main sources of fossil fuels in the SW Gulf of Mexico.

Microbiological data indicate that the impact on surface waters and sediments caused by seasonal or sporadic oil inputs produces seasonal or rapid and drastic changes in oil-degrader percentages both in coastal lagoons and the offshore oil-production area. The concentration of oil-degraders (OD) has always been important in water $\left(10^{1}-10^{4} \mathrm{OD} \mathrm{ml}^{-1}\right)$ and sediments $\left(10^{1}-10^{5} \mathrm{OD} \mathrm{g}^{-1}\right)$; this revealed the existence of a diverse bacterial consortium in the SW Gulf capable of participating in oil biodegradation processes.

In summary, the bacterial oil degraders/heterotrophic bacteria percentage $(\mathrm{OD} / \mathrm{HB})$ had not shown any accumulative or permanent oil impact on Campeche Sound, since the Ixtoc-I blowout in 1979, until 1985. Fresh and estuarine waters and sediments exposed to chronic oil inputs from continental sources exhibited seasonal changes. However, at the PEMEX's offshore oil-extraction area, drastic changes in this index were recorded bimonthly, with no indication of an increase in the oil concentration, particularly at the most active platforms. This was later confirmed by Leahy et al. (1990) who explained that such conditions were attributed to low-mineralization rates and nutrient limitation. Therefore, oil impact seemed to be confined to a limited area around river deltas and oil platforms.

\section{OIL SPILL EFFECTS ON PHYTOPLANKTON}

The historical data of chlorophyll- $a$ concentrations from the SW Gulf of Mexico estimated by traditional methods and through satellite images prior and after 1979s Ixtoc-I oil blowout confirmed its rich primary productivity (Licea and Santoyo, 1991; Müller-Karger et al., 1991; Licea and Luna, 1999; Salmerón-García et al., 2011). In the marine ecosystem, phytoplankton represents the basic trophic level in the food web and under stress conditions send out the first warning signs of environmental disturbance.

Licea et al. (1982) in their study of the possible effects of the Ixtoc-I oil spill to the phytoplankton, were able to recognize harmful damages on the phytoplankton community of Campeche Sound. They reported a significant decrease (local and seasonal) in biomass, primary productivity and diversity index. According to these authors, not all the phytoplankters have the same response when they are exposed to crude oil and to chemical dispersants (Corexit ${ }^{\circledR}$ ). Some of the most susceptible species are the small phytoflagellates (Chlorophyceae, Prasinophyceae, Euglenophyceae Prymnesiophyceae).

Unfortunately, current field observations and experimental studies of the effects of oil spills on phytoplankton are limited and often contradictory. However, there is sufficient proof of the deleterious effects that petroleum hydrocarbons have upon photosynthesis and phytoplankton growth (González et al., 2009; Jung et al., 2012). Recent laboratory toxicity tests suggest that the chemical dispersants increase the oil toxicity causing membrane damage in diatom cells (Hook and Osborn, 2012). Diatoms predominated throughout the 9 months of the Ixtoc-I oil spill in Campeche Sound. One may infer then that the observed sequential changes described in the community structure of plankton by Licea et al. (1982) and Guzman del Próo et al. (1986) were possibly caused by the disruption of the pelagic food web.

Presently, there are still many environmental uncertainties in relation to the persistence and weathering factors of crude oil in the marine ecosystem. Oil residues and chemical dispersants are known to persist in the marine environment for many years (Kingston, 2002). Perhaps, there are no unequivocal answers concerning the Ixtoc-I accident in the SW Gulf of Mexico. However, this does not necessarily imply that the ecological equilibrium of the marine ecosystem in Campeche Sound remained unaltered, during and after the oil spill. For instance, there were obvious 
evidence in the abundance and composition of the phytoplankton assemblages in the region Licea-Durán (1977), Licea et al. (2004, 2011) and Zamudio-Resendis et al. (2013). Other changes were more subtle and should be considered as "none-detectable effects" given the difficulty involved in distinguishing natural from oil-induced variability.

\section{DEMERSAL FISH COMMUNITY ASSESSMENT}

The lessons learned from the Ixtoc-I blowout cover a broad spectrum. For instance, an estimated recruitment under equilibrium conditions is quite straightforward and would consist simply of dividing an estimate of yield-per-recruit into an average catch, or biomass-per-recruit into an average biomass. However, egg production from the spawned pool appears to be the main problem toward computing recruitment in tropical coastal demersal communities. The fundamental problems related to such studies are (fide Yáñez-Arancibia and Pauly, 1986; Baltz and Yáñez-Arancibia, 2013): (1) the species have a clear separation of habitat in the eggs and the juvenile and adult stages; (2) in a multi stock context eggs and larvae are often taxonomically indistinguishable; (3) strong biotic interactions among the different species, especially trophic competition and predation in the juvenile stages, exist; (4) life cycles are short, often less than 1 year and recruitment is often continuous in species with interspecific programming among them. The separation of the different biological stages and the trophic dynamic about different habitats suggest close ties between fishes, the specific characteristics of their habitats and trophic dynamics, masking the vulnerability to oil exposure.

We concentrate on fishes because they constitute the overwhelming bulk (up to 99\%) of the coastal-marine nekton both in terms of number and biomass. Since much information is now available on the life cycles of fishes in relation to lagoon-estuarinesea shelf environment, various schemes have been proposed to link these cycles with environmental quality parameters and the observed high abundance of fishes in the tropical coastal zone (Yáñez-Arancibia et al., 1994). Most of the information, concerning the Ixtoc-I oil spill already published was obtained between 1976 and 1982, just before and just after the Ixtoc-I oil spill. Some important points have emerged from these studies (YáñezArancibia et al., 1994; Baltz and Yáñez-Arancibia, 2013):

- The utilization of the lagoon-estuarine environment is an integral part of the life cycle of numerous fishes, particularly in tropical and subtropical latitudes;

- The lagoon-estuarine environment is utilized mainly by juveniles and young adults;

- The inner shelf environment (estuarine plume) is utilized mainly by adults and spawners;

- There is a greater number of fish species in tropical and subtropical coastal ecosystems than there is incomparable temperate or boreal systems;

- Second-order consumers are more abundant and, more diverse than first-order consumers, or top carnivores. Second-order consumers who are the most common commercial fish stocks can accumulate toxic substances in fat tissue and muscles;

- Three temporal groupings of fish occur in the coastal ecosystems in the Gulf of Mexico: (a) resident species, those that spend their entire life cycle within estuaries, lagoons or coastal wetlands, (b) seasonal migrants, those that enter the estuary during a fairly well-defined season from either the marine or the freshwater side and leave it during another season and (c) occasional visitors, those that enter and leave the estuary and associated coastal wetlands with no clear pattern with the passage of time; and,

- To these, two other groups may be added: (d) marine, estuarine-related species, those that spend their entire life cycle on the inner sea shelf under the estuarine plume influence; and (e) freshwater, estuarine-related species, those that spend their entire life cycle in the fluvial-deltaic river zone, associated with the upper zone of the estuarine system.

As a consequence, if the "recruitment" both biological and fishery-related, utilizes estuaries/coastal lagoons/wetlands, these resources are "estuarine-dependent"; but if they regularly utilize the option of the estuarine plume on the continental shelf, they are "estuarine-related" or estuarine-opportunistic (YáñezArancibia and Pauly, 1986). Classifications of this type can be constructed, somewhat rigorously for any desired level of resolution, using clustering-type techniques published after the Ixtoc-1 oil spill by Yáñez-Arancibia et al. (1982), Yáñez-Arancibia (1985, 1986). These are now extremely useful to determine if freshwater fish spawners occur in water with less than 10 psu (salinity). Brackish water groups are limited to 10-34 psu and typical marine spawners are found in waters higher than 34 psu. These references in addition to the results on the abundance in fish numbers and biomass, correlated with diversity and abundance indices were enough information to establish that the oil spill impact was almost absent 30 years ago in the short-time period before and after the Ixtoc-I blowout.

A number of factors were related to explain the low environmental impact on demersal fish communities (Yáñez-Arancibia et al., 1982; Yáñez-Arancibia, 1986): (1) the circulation pattern of coastal waters and residual currents onto the inner shelf in the area; (2) the strong estuarine plume acting as a hydrological barrier between the sea and the coastal wetlands, mainly from Términos Lagoon and the Grijalva-Usumacinta River deltaic system; (3) the metabolism of the water column with temperatures higher than $25^{\circ} \mathrm{C}$; (4) the biological strategies of coastal fishes and the short life history in less than 1 year; and (5) the rapid energetic changes in the ecological system.

Over 30 years ago it was not possible to say anything about a long-time period after the oil spill, because no information was available on deleterious, acute or chronic impacts; Thirty years after the Ixtoc-I oil spill, this demersal fish community's assessment, is at present, the "fingerprint" to evaluate and quantify future oil-spill impact in Campeche Sound.

\section{FISH LANDING TRENDS IN CAMPECHE SOUND}

The shrimp landings in Campeche Sound (Figure 2) have diminished from nearly 20,000 $\mathrm{t}$ in 1970 to a meager $500 \mathrm{t}$ in recent years (Castro-Meléndez et al., 2000). The local fishing authorities have enforced a population management plan in this region of the Gulf to avert the bio-economic collapse of this important activity. The plan consists of establishing close-seasons to reduce 


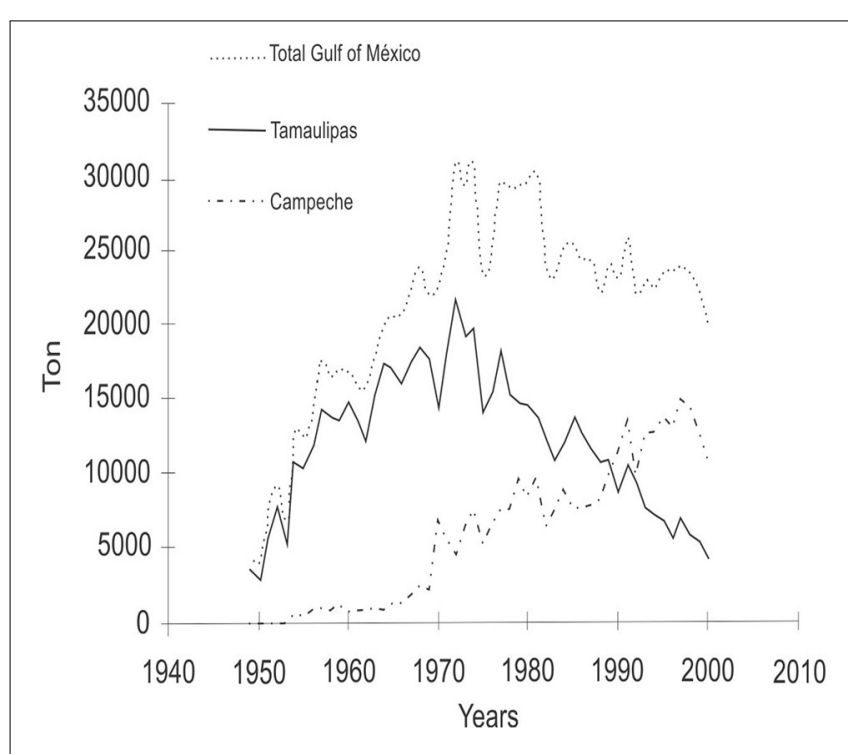

FIGURE 2 | Total shrimp landings in the Gulf of Mexico and in the coasts of Tamaulipas and Campeche, Mexico. (Modified from Díaz de León et al., 2004).

fishing mortality in an attempt to protect the reproductive stock and to promote early juvenile recruitment. The close-season regulation in Campeche Sound that extends from May to October has been implemented since 1993. However, the most recent fishing statistic records still reveal a declining trend $(<2000 \mathrm{t}$ in 2004; Zetina-Rejón et al., 2001), which is a clear indication that both recruitment to the adult stock and the offshore reproductive population have not fully recovered yet (Figure 2).

Díaz de León et al. (2004) in their assessment of the Mexican fishing resources and environment, have sounded the alarm on the significant reduction (20\%) of the total fish catch in the Gulf of Mexico due to overfishing practices in marine and inshore waters. According to these authors, $79 \%$ of the fishing resources of the Gulf have already reached their maximum sustainable yield (MSY) and 25\% of such resource is on the verge of collapsing. It is interesting though that in their assessment of fishing resources of the Gulf, they vaguely allude to the deterioration of the ecosystem as a possible cause for their rather grim outlook. Their prediction concerning Campeche Sound is that this region faces the greatest ecological risk because of the ongoing oil extraction and the increasing catch per unit effort.

\section{DISCUSSION ON THE ENVIRONMENTAL HEALTH OF CAMPECHE SOUND}

Ever since the oil and gas exploration and extraction conducted by the Mexican oil consortium PEMEX expanded its offshore operations in the SW Gulf in 1974, there has been an immediate concern for the socio-economical and environmental transformation that the presence of this aggressive industry would have upon the local communities. Social confrontations and legal suits filed against PEMEX, by social and conservation groups before State and Federal agencies due to ecological damages caused by accidental and chronic oil spills are now part of long litigation processes, minimized with subsidy compensations and damage bio-remediation actions.

The demersal fish community is a vital link in transferring contaminants from the sediment to higher trophic levels, and the demersal-benthic fishes included- community structure is sensitive to petroleum hydrocarbon exposure (Baltz and YáñezArancibia, 2013). The ecological and biological effects of energy development on coastal marshes and estuarine environments are broad and sometimes persistent and include mortality, growth inhibition, reduced production, altered metabolic systems and tainted flesh in fish and shellfish. Oil and gas production and transportation on the coastal shelf and wetlands in the Gulf of Mexico (e.g., Veracruz, Tabasco, Campeche) have resulted in the accumulation of polycyclic aromatic hydrocarbons $(\mathrm{PAH})$ and heavy metals in affected areas (e.g., Boehm et al., 2001; Botello et al., 2004; Gold-Bouchot, 2004; Ko and Day, 2004). These compounds cause ecological disturbances, including alteration of the aquatic community structure and food chains. Undoubtedly, the hydrocarbon chemistry is a complex research issue that requires innovative analytical techniques (see Reddy et al., 2002). In tropical environments, oil spills may have catastrophic consequences as occurred on the Caribbean coast of Panama (Burns et al., 1994; Burns and Yelle-Simmons, 1994; Garrity et al., 1994; Levings et al., 1994). Severe effects to the physical structure of mangrove forest and seagrass beds are caused by residual hydrocarbons compounds and more importantly, the perspective of ecological recovery may take on the order of decades. Medium weight aromatic hydrocarbons may persist for at least 20 years post-spill in mangrove sediments (Corredor et al., 1990).

High biodiversity and population density of the fish community in a short period (1978-1982) including the Ixtoc-I oil spill (1979-1980) discussed by Yáñez-Arancibia $(1985,1986)$, are different and significantly lower in the contaminated coastal wetlands areas in the Gulf of Mexico 30 years later (Cowan et al., 2008; Baltz and Yáñez-Arancibia, 2013). Those authors attribute the present reduced fish diversity and biomass to hypoxia, climate change, oil and gas exploitation and overfishing.

García-Cuéllar et al. (2004) and Soto and González (2009) have reviewed and assessed PEMEX's offshore operations in the past two decades and their potential ecological impact in Campeche Sound. Both publications recognized the lack of reliable baseline data needed to undertake such a challenging task. This was the main impediment argued by García-Cuéllar et al. (2004) to admit finally that they did not have sufficient evidence to prove environmental damages attributed to all the PEMEX operations listed in their publication.

In contrast, Soto and González (2009), documented the harmful effects caused by bioaccumulation of heavy metals and hydrocarbons in shellfish (oysters and clams), the disruption caused by oil spills in sea grasses, the submerged vegetation of neighboring estuarine systems in Campeche and Tabasco littorals and the bioaccumulation of hydrocarbons in shrimp tissues captured within the PEMEX Restricted Area. These authors contend that the ecological disturbances originated from the presence of the oil industry in the past two decades are severe near the areas where drilling and oil and gas extraction take place in Campeche Sound. Downstream from the Restricted Area, such effects are attenuated 
by the resilient capacity of the oceanic ecosystem as a whole (plankton-zooplankton-benthos-nekton), and consequently the oil disturbance signals mainly caused by low molecular- weight hydrocarbons, are difficult to detect. However, the most vulnerable ecological components are inshore inhabitants such as oysters, clams, and mussels. Botello et al. (1983) clearly documented high concentrations of polycyclic aromatic hydrocarbons (PAHs), particularly of naphthalene and their methyl derivatives in the oyster Crassostrea virginica and sediments from the coastal lagoons in Tabasco that there were directly associated with Ixtoc-I crude oil.

Undoubtedly, there are many points of controversy among different authors when they are confronted with the analysis and interpretation of the magnitude of environmental damages caused by the oil industry in the marine ecosystem. Holdway (2002) has even proposed as a possible solution for long-term environmental observation (10-20 years) to determine chronic and sublethal effects attributable to offshore oil exploitation. However, there is a consensus in accepting that acute toxic effects are space restricted and of short duration, whereas, the midand long-term or sublethal stress are more difficult to assess and eventually become non-detectable (Burns and Yelle-Simmons, 1994). Another lesson learned from the Ixtoc-I blowout is that the pelagic realm recovers faster from a massive oil spill than the benthic compartment. Oil degradation rates and weathering processes in sediments may take much longer time (see Boehm and Fiest, 1982; Oudot and Chaillan, 2009) in the scale of several decades. Factors like the spilt oil volume, the high carbon content, anoxic conditions that hinder microbial degradation and a low-energy environment may all contribute to the indefinite persistence of hydrocarbons in sediments (Reddy et al., 2002).

In recent times, the environmental conditions in the southwestern Gulf of Mexico have been further aggravated by the rapid expansion of PEMEX's coastal and offshore operations. Accidental spills have again occurred in this area, thus raising new concerns for the fate of habitats known for their ecological value as spawning, nursery and feeding grounds for marine and estuarine-dependent species. One should understand the complications involved in offering unequivocal evidence of environmental damages caused by accidental oil spills knowing in advance the physicochemical and biological processes acting at different spatial and temporal scales. On the positive side, new research lines (genetics and molecular biology) are beginning to shed some light on this problem. In reference to the long-term oil effects at the population level, some colleagues are attempting to explain in the case of penaeid shrimp in Campeche Sound that the loss of genetic variability and the immune response can result from the continuing exposure to oil-related activities and hydrocarbon discharges. Presently we have at our disposal much better scientific tools (biomarkers and isotopic tracers) that can contribute to the unraveling of the complexity of oil pollution in the marine environment.

\section{SUMMARY}

Tropical marine systems maintain a delicate ecological balance among its different compartments (phytoplankton-zooplanktonbenthos-nekton) that can easily be upset by anthropogenic disturbances. Major oil spills in the Gulf of Mexico are prone to cause acute and long-term ecological effects. However, there seems to be a consensus in accepting that chronic oil pollution is eventually more harmful to the environment of Campeche Sound, southwestern Gulf of Mexico, than accidental oil spills.

In the particular case of the Ixtoc-I oil blowout, the reconstruction of ecological scenarios to assess the environmental damages detected in the southwestern Gulf of Mexico is a major challenge. The lack of a baseline data bank and a reliable source on the space-time variability on a number of environmental parameters preclude any efforts focused on reaching a conclusive answer concerning the mid-and long-term ecosystem response to a catastrophic oil spill.

Several authors have argued, in an attempt to understand the immediate ecosystem response to a massive oil spill caused by the Ixtoc-I blowout, that its first critical phase was perhaps progressively alleviated by a weathering process activated by local atmospheric, hydrological and biological conditions prevailing in the southwestern Gulf of Mexico. However, contrary to the official position of Mexican agencies that adamantly insisted that no environmental damages were caused by Ixtoc-I, oil residues remained in the water and sediments. These were absorbed by filtering organisms and bio-accumulated by benthic fauna such as oysters (Crassostrea virginica) and clams (Rangia cuneata and Polymesoda carolineana), particularly in coastal lagoon systems of the States of Campeche and Tabasco. The main fishery resource in this region of the Gulf, the penaeid shrimps, has experienced a declining production trend since the late 1970s, but despite all the fishery management regulations implemented since 1989, the pink shrimp population, which sustains this fishery, is at a great risk of suffering a collapse.

The Ixtoc-I legacy is a painful reminder of the fallibility of the offshore technology employed in the exploitation of fossil fuels contained in the seabed. It also underlines the ecological fragility of coastal habitats; but more importantly, it emphasizes our inadequate knowledge on the mid- and long-term response of tropical marine ecosystem exposed to accidental oil spills. Unfortunately, the sinking of the Deepwater Horizon drilling rig and the subsequent release of 4.9 million barrels of crude oil in the northern Gulf of Mexico in 2010 rekindles another environmental tragedy with the loss of human lives and escalates our concern to achieve a proper social and economic sustainable development for Mexico.

\section{ACKNOWLEDGMENTS}

The authors express their gratitude to Edwin W. Cake, Jr., for his invaluable comments and suggestions to an early version of this manuscript. Thanks are extended to the reviewers for the critical evaluation of this contribution. A. Estrada helped editing the text.

\section{REFERENCES}

Antoine, W. J. (1972). "Structure of the Gulf of Mexico," in Contributions on the Geological and Geophysical Oceanography of the Gulf of Mexico, ed R. Rezak (Houston, TX: Gulf Publishing Co.), 134.

Baltz, D. M., and Yáñez-Arancibia, A. (2013). "Ecosystem-based management of coastal fisheries in the Gulf of Mexico: environmental and anthropogenic impacts and essential habitat protection, Chapter 19: 337-370," in The Gulf of Mexico Origin, Water, and Biota, Vol. 4 Ecosystem-Based Management, eds J. W. Day and A Yáñez-Arancibia (College Station, TX: Texas A\&M University Press), 460. 
Boehm, P. D., and Fiest, D. L. (1982). Subsurface distribution of petroleum from an offshore well blowout. The Ixtoc-I blowout, Bay of Campeche. Env. Tech. 16, 67-74.

Boehm, P. D., Turton, D., Raval, A., Caudle, D., French, D., Rabalais, N., et al. (2001). "Deepwater program: literature review," in Environmental Risk of Chemical Products used in Gulf of Mexico Deepwater Oil and Gas Operation, Volume I: Technical Report. Outer Continental Shelf (OCS) Study MMS 2001-011 (New Orleans, LA: Minerals Management Service, Gulf of Mexico OCS Region), 326.

Botello, A. V. (1996). "Características, composición y propiedades fisicoquímicas del petróleo," in Golfo de México, Contaminación e Impacto Ambiental: Diagnóstico y Tendencias. Serie Científica EPOMEX 5, 666, eds A. V. Botello, J. L. Rojas Galaviz, J. A. Benítez y, and D. Zárate Lomelí (Campeche: Univ. Autón. de Campeche), 203-210.

Botello, A. V., and Castro, S. (1980). "Chemistry and natural weathering of various crude oil fractions from the Ixtoc-I oil spill," in Proceedings Symposium Ixtoc-I Oil Spill (Key Biscayne, FL: U.S. Dept. Commerce, NOAA), 387-407.

Botello, A. V., Goñi, J. A., and Castro, A. (1983). Levels of organic pollution in coastal lagoons of the Tabasco State, Mexico, I: petroleum hydrocarbons. Bull. Eviron. Contam. Toxicol. 31, 271-277.

Botello, A. V., González, C., and Díaz, G. (1991). Pollution by petroleum hydrocarbons in sediments from Continental shelf of Tabasco State, Mexico. Bull. Environ. Contam. Toxicol. 47, 565-571.

Botello, A. V., Rendón von Osten, J., Gold-Bouchot, G., and Agraz-Hernández, C. (Eds.) (2005). Golfo de México, Contaminación e Impacto Ambiental: Diagnóstico $y$ Tendencias, 2 Edición. Campeche Univ.: Campeche-UNAM-INE-SEMARNAT, 696.

Botello, A. V., and Villanueva, S. F. (1987). Vigilancia de Los Hidrocarburos Fósiles en Sistemas Costeros del Golfo de México y Áreas Adyacentes I: Sonda de Campeche. Vol. 14. México, D.F.: Anales del Instituto de Ciencias del Mar y Limnología. UNAM, 45-52.

Botello, A. V., Villanueva, S., and Rosales Hoz, L. (2004). "Distribución y contaminación de metales en el golfo de México," in Diagnóstico Ambiental del Golfo de Mexico, Vol. 2, eds M. Caso, I. Pisanty, and E. Ezcurra (Mexico, DF: Instituto Nacional de Ecología INE, Instituto de Ecologia A. C. INECOL, and Harte Research Institute for Gulf of Mexico Studies. Texas A\&M University-Corpus Christi, SEMARNAT), 683-712.

Burns, K. A., Garrity, S. D., Jorissen, D., MacPherson, J., Stoelting, M., Tierney, J., et al. (1994). The Gaketa Oil Spill. II. Unexpected persistence of oil trapped in mangrove sediments. Estuar. Coast. Shelf Sci. 38, 349-364.

Burns, K. A., and Yelle-Simmons, L. (1994). The Galeta oil spill. IV. Relationship between sediment and organism hydrocarbon loads. Estuar. Coast. Shelf Sci. 38, 397-412

Castro-Meléndez, R. G., Schultz, L. E., Wakida Kusunoki, A. T., and Fernández Méndez, J. I. (2000). "Camarón del Golfo de México y del Caribe: 357-420," in Sustentabilidad y Pesca Responsable en México: Evaluación y Manejo, ed I. Aguilar 1999-2000 (México, D.F.: Inst. Nal. de Pesca), 691.

Corredor, J. E., Morrell, J. M., and De Castillo, C. E. (1990). Persistence of spilled crude oil in a tropical intertidal environment. Mar. Poll. Bull. 21, 385-388.

Cowan, J. H., Grimes, C. B., and Shaw, R. F. (2008). Life history, history, hysteresis, and habitat change in Louisiana's coastal ecosystems. Bull. Mar. Sci. 83, 197-215.

Díaz de León, A., Fernández, J. I., Álvarez-Torres, P., Ramírez-Flores, O., and López-Lemus, L. G. (2004). "La sustentabilidad de las pesquerías del Golfo de México: 727-755," in Diagnóstico Ambiental del Golfo de México, Vol. I-II, eds M. Caso, I. Pisanty, and E. Ezcurra (Mexico, D.F: SEMARNAT-INE-Harte Res. Inst.)

García-Cuéllar, J. A., Arreguín-Sánchez, F., Hernández-Vázquez, S., and LluchCota, D. B. (2004). Impacto ecológico de la industria petrolera en la Sonda de Campeche, México, tras tres décadas de actividad: una revisión. Interciencia 29, 311-319.

Garrity, S. D., Levings, S. C., and Burns, K. A. (1994). The Galeta oil spill. I. Longterm effects on the physical structure of the mangrove fringe. Estuar. Coast. Shelf Sci. 38, 327-348.

Gold-Bouchot, G. (2004). "Hidrocarburos en el sur del Golfo de México," in Diagnostico Ambiental del Golfo de Mexico, Vol. 2, eds M. Caso, I. Pisanty, and E. Ezcurra (México, D.F.: Instituto Nacional de Ecología INE, Instituto de Ecologia A. C. INECOL, and Harte Research Institute for Gulf of Mexico Studies. Texas A\&M University-Corpus Christi, SEMARNAT), 657-682.
González, J., Figueiras, F. G., Aranguren-Gassis, M., Crespo, B. G., Fernández, E., Morán, X. A. G., et al. (2009). Effect of a simulated oil spill on natural assemblages of marine phytoplankton enclosed in microcosms. Estuar. Coast. Shelf Sci. 83, 265-276. doi: 10.1016/j.ecss.2009.04.001

Guzman del Próo, S. A., Chávez, E. A., Alatriste, F. M., de la Campa, S., de la Cruz, G., Gómez, L., et al. (1986). The impact of the Ixtoc-1 oil spill on zooplankton. J. Plankton Res. 8, 557-581.

Hernández, H., Gold-Bouchot, G., Bustamante, J., Ceja-Tapia, V., and del Río, M. (2003). IV Foro Regional de Camarón y Mar Caribe, Campeche, Campeche. 26-28 de Febrero. México, D.F. (Resumen): Inst. Nal. Pesca, Gob. de Campeche-CRIPLerma.

Holdway, D. (2002). The acute and chronic effects of wastes associated with offshore oil and gas production on temperate and tropical marine ecological processes. Mar. Pollut. Bull. 44, 185-203. doi: 10.1016/S0025-326X(01) 00197-7

Hook, S. E., and Osborn, H. L. (2012). Comparison of toxicity and transcriptomic profiles in a diatom exposed to oil, dispersants, dispersed oil. Aquat. Toxicol. 124-125, 139-151. doi: 10.1016/j.aquatox.2012.08.005

Jernelöv, A., and Lindén, O. (1981). Ixtoc-I: a case study of the world's largest oil spill. Ambio 10, 299-306.

Jung, S. W., Kwon, O. Y., Joo, C. K., Kang, J. H., Kim, M., Shim, W. J., et al. (2012). Stronger impact of dispersant plus crude oil on natural plankton assemblages in short-term marine mesocosms. J. Hazard. Mater. 217-218, 338-349. doi: 10.1016/j.jhazmat.2012.03.034

Kingston, P. F. (2002). Long-term Environmental Impact of Oil Spill. Spill Sci. Tech. Bull. 7, 53-61. doi: 10.1016/S1353-2561(02)00051-8

Ko, J. Y., and Day, J. W. (2004). "Wetlands: impact of energy development in the Mississippi Delta," in The Encyclopedia of Energy, Vol. 6, ed C. Cleveland (Amsterdam: Elsevier), 397-408.

Kumpf, H., Steidinger, K., and Sherman, K. (1999). The Gulf of Mexico Large Marine Ecosystem: Assessment, Sustainability and Management. Malden, MA: Blackwell Science Ltd., 704.

Leahy, J. G., Somerville, C. C., Cunningham, K. A., Adamantiades, G. A., Byrd, J. J., and Colwell, R. R. (1990). Hydrocarbon mineralization in sediments and plasmid incidence in sediment bacteria from the Campeche Bank. Appl. Environ. Microbiol. 56, 1565-1570.

Levings, S. C., Garrity, S. D., and Burns, K. A. (1994). The Galeta oil spill. III. Chronic reoiling, log-term toxicity of hydrocarbon residues and effects on epibiota in the mangrove fringe. Estuar. Coast. Shelf Sci. 38, 365-395.

Licea, S., and Luna, R. (1999). Spatio-temporal variation of phytoplankton on the continental margin in the SW Gulf of Mexico. Rev. Soc. Mex. Hist. Nat. 49, 83-99.

Licea, S., Luna, R., Torres, P., and Trejo, C. (1982). Informe Final del Proyecto de Investigación "Evaluación de los Posibles Efectos del Derrame del Pozo Ixtoc-I, Sobre Las Comunidades del Fitoplancton y la Productividad Primaria. Ibid. (Sexto informe): 1-44, 16 figs., 11 tablas.

Licea, S., and Santoyo, H. (1991). Algunas Características Ecológicas Del Fitoplancton de la Región Central de la Bahía de Campeche. México, D.F.: An. Inst. Cienc. del Mar y Limnol. Univ. Nal. Autón. Vol. 18, 157-167.

Licea, S., Zamudio, M. E., Luna, R., and Soto, J. (2004). Free living dinoflagellates in the southern Gulf of Mexico. Phycol. Res. 52, 419-428. doi: 10.1111/j.14401835.2004.tb00351.x

Licea, S., Zamudio, M. E., Moreno-Ruiz, J. L., and Luna, R. (2011). A suggested local regions in the Southern Gulf of Mexico using a diatom data-base (1979-2002) and oceanic hydrographic features. J. Environ. Biol. 32, 443-453.

Licea-Durán, S. (1977). Variación estacional del fitoplancton de la Bahía de Campeche, México (1971-1972). FAO Fish. Rep. 200, 253-273.

Lizárraga-Partida, M. L. (1996). "Microbiología del petróleo en el Sur del Golfo de México," in Contaminación e Impacto Ambiental: Diagnóstico y Tendencias, Vol. 5, eds A. V. Botello, J. L. Galaviz, J. A. Benítez, and D. Zárate-Lomelí (Golfo de México: Univ. Autón. de Campeche. Serie Científica EPOMEX), 265-278, 666.

Lizárraga-Partida, M. L., Izquierdo-Vicuña, F. B., and Wong-Chang, I. (1991). Marine bacteria on the Campeche bank oil field. Mar. Pollut. Bull. 22, 401-405.

Lizárraga-Partida, M. L., Rodriguez-Santiago, H., and Romero-Jarero, J. (1982). Effects of Ixtoc-I blowout on heterotrophic bacteria. Mar. Pollut. Bull. 11, $67-70$.

Müller-Karger, F. E., Walsh, J., Evans, R. H., and Meyers, M. B. (1991). On the seasonal phytoplankton concentration and sea surface temperature cycles of the Gulf of Mexico as determined by satellites. J. Geophy. Res. 96, 12.645-12.665. 
Oudot, J., and Chaillan, F. (2009). Pyrolysis of asphaltenes and biomarkers for the fingerprinting of the Amoco-Cadiz oil spill after 23 years. Nat. Prec. 13, 548-552. doi: 10.106/J.crci.2009.12.002

PC-EESC. (1980). Informe de los Trabajos Realizados para el Control del Pozo Ixtoc1, el Combate del Derrame de Petróleo y Determinación de sus Efectos sobre el Ambiente. Programa Coordinado de Estudios Ecológicos en la Sonda de Campeche (PC-ESSC). México, D.F.: Impreso por Instituto Mexicano del Petróleo, 242.

Reddy, C. M., Eglinton, T. I., Houndshell, A., White, H. K., Li, X.,Gaines, R. B., et al. (2002). The West Falmouth oil spill after thirty years: the persistence of petroleum hydrocarbons in marsh sediments. Environ. Sci. Technol. 36, 4754-4760. doi: 10.1021/es020656n

Salmerón-García, O., Zavala-Hidalgo, J., Mateos-Jasso, A., and Romero-Centeno, R. (2011). Regionalization of the Gulf of Mexico from space-time chlorophyll- $a$ concentration variability. Ocean Dynam. 61, 439-448. doi: 10.1007/s10236-0100368-1

Seijo, J. C., Caddy, J. F., Arzápalo, W. W., and Cuevas-Jiménez, A. (2013). "Considerations for an ecosystem approach to fisheries management in the Southern Gulf of Mexico, Chapter 18: 319-336," in The Gulf of Mexico Origin, Water, and Biota, Vol. 4 Ecosystem-Based Management, eds J. W. Day and A. Yáñez-Arancibia (College Station, TX: Texas A \& M University Press), 460.

Sherman, K. (1994). Sustainability, biomass yield, and health of coastal ecosystems: an ecological perspective. Mar. Ecol. Progr. Ser. 112, 277-301. doi: $10.3354 /$ meps 112277

Soto, L. A., and Escobar-Briones, E. (1995). "Coupling mechanisms related to benthic production in the SW Gulf of Mexico," in Biology and Ecology of Shallow Waters, Proceedings of the 28th European Marine Biology Symposium, Olsen and Olsen, Denmark, eds A. Eleftheriou, A. Ansell, and C. J. Smith (Fredensborg), 233-242.

Soto, L. A., Estradas, A., Herrera, R., Montoya, A., Ruiz, R., Corona, A., et al. (2009). "Biodiversidad Marina en la Sonda de Campeche," in Pemex y La Salud Ambiental de la Sonda de Campeche, eds L. A. Soto y and C. González (México, D.F.: IMP-UNAM-BATTELLE-UAM), 265-300.

Soto, L. A., and González, C. (2009). Pemex y La Salud Ambiental de la Sonda de Campeche. México, D.F.: IMP-UNAM-BATTELLE-UAM, 397.

Soto, L. A., Gracia, A., and Botello, A. V. (1981). Study of the penaeid shrimp population in relation to petroleum hydrocarbons in Campeche Bank. Proc. Gulf Carib. Fish. Inst. 33:100.

Villalobos-Zapata, G. J. (2010). “Áreas Naturales Protegidas en Campeche,"in En. La Biodiversidad en Campeche: Estudio de Estado, eds Univ. Autón.de Campeche. ECOSUR (Campeche: COABIO. Gob. Campeche.), 580-587, 724.

Yáñez-Arancibia, A. (Ed.) (1985). Fish Community Ecology in Estuaries and Coastal Lagoons: Towards and Ecosystem Integration. México, D.F.: UNAM, PUAL, ICML, UNAM Press, 650.

Yáñez-Arancibia, A. (1986). "Ecología, impacto ambiental y recursos pesqueros: El caso del Ixtoc-1 y los peces, Capítulo 5: 95-126," in Ecología de la Zona Costera Análisis de Siete Tópicos, ed A. Yáñez-Arancibia (México, D.F.: AGT Editorial), 180.

Yáñez-Arancibia, A., and Day, J. W. (2004). Environmental sub-regions in the Gulf of Mexico coastal zone: the ecosystem approach as an integrated management tool. Ocean Coast. Manage. 47, 727-757. doi: 10.1016/j.ocecoaman.2004.12.010

Yáñez-Arancibia, A., Day, J. W., Lara-Dominguez, A. L., Sánchez-Gil, P., VillalobosZapata, G. J., and Herrera-Silveira, J. A. (2013a). "Ecosystem functioning, the basis for sustainable management of Terminos Lagoon, Campeche Mexico, Chapter 9: 167-199," in The Gulf of Mexico Origin, Water, and Biota, Vol. 4 Ecosystem-Based Management, eds J. W. Day and A. Yáñez-Arancibia (College Station, TX: Texas A \& M University Press), 460.

Yáñez-Arancibia, A., Day, J. W., and Reyes, E. (2013b). "Understanding the coastal ecosystem-based management approach in the Gulf of Mexico," in
Understanding and Predicting Change in the Coastal Ecosystems of the Northern Gulf of Mexico, Journal of Coastal Research, Special Issue No. 63, eds J. C. Brock, J. A. Barras, and S. J. Williams (Coconut Creek, Fl: Coastal Education and Research Foundation, Inc.), 244-262.

Yáñez-Arancibia, A., Lara-Domínguez, A. L., and Pauly, D. (1994). "Coastal lagoons as fish habitats, Chapter 12: 363-376," in Coastal Lagoon Processes, Oceanography Series 60, ed B. Kjerfve (Amsterdam: Elsevier Science B.V.), 578.

Yáñez-Arancibia, A., Lara-Domínguez, A. L., Sánchez-Gil, P., Álvarez, H., Vargas, I., Aguirre, A., et al. (1982). Caracterización Ambiental del Sistema Ecológico y Análisis Comparativo de las Poblaciones de Peces de la Sonda de Campeche y de la Laguna de Términos antes y Después del Derrame Petrolero del Pozo IXTOC-I (Informe Final). PC-EESC/UNAM/ICML (IF), 4 partes, 211 páginas, 22 tablas, 49 figuras, +mapas.

Yáñez-Arancibia, A., Lara-Domínguez, A., Sánchez-Gil, P., and Day, J. W. (2007). "Estuary-sea ecological interactions: a theoretical framework for management of coastal environment, Chapter 14: 271-301," in Environmental Analysis of the Gulf of Mexico. Harte Research Institute for Gulf of Mexico Studies Special Publication Series No. 1, eds K. Withers and M. Nipper (Corpus Christi, TX: Texas A\&M University Press), 700.

Yáñez-Arancibia, A., and Pauly, D. (Eds.) (1986). "IOC/FAO workshop on recruitment in tropical coastal demersal communities," in Workshop Report 44. Intergovernmental Oceanographic Commission (UNESCO, Paris), 333.

Yáñez-Arancibia, A., Ramírez Gordillo, J. J., Day, J. W., and Yoskowitz, D. (2009). "Environmental sustainability of economic trends in the Gulf of México: what is the limit for Mexican coastal development? Chapter 5: 82-104," in Ocean and Coastal Economy. Gulf of Mexico Origin, Waters, and Biota Series, Vol. 2, ed J. C. Cato (College Station, TX: Texas A\&M University Press), 110.

Zamudio-Resendis, M. E., Licea, S., and Luna, R. (2013). "Relative abundance and distribution of some unarmored dinoflagellates species in the Southern Gulf of Mexico (2005-2010)," in Biological and Geological Perspectives of Dinoflagellates. The Micropalaeontological Society, Special Publications, eds J. M. Lewis, F. Marret, and L. Bradley (London: Geological Society), 233-238.

Zetina-Rejón, M., Arreguín-Sánchez, F., and Chávez, E. (2001). Using an ecosystem modeling approach to assess the management of a Mexican coastal lagoon system. CalCOFI Rep. 42, 78-90.

Conflict of Interest Statement: The authors declare that the research was conducted in the absence of any commercial or financial relationships that could be construed as a potential conflict of interest.

Received: 25 August 2014; accepted: 20 October 2014; published online: 07 November 2014.

Citation: Soto LA, Botello AV, Licea-Durán S, Lizárraga-Partida ML and YáñezArancibia A (2014) The environmental legacy of the Ixtoc-I oil spill in Campeche Sound, southwestern Gulf of Mexico. Front. Mar. Sci. 1:57. doi: 10.3389/fmars. 2014.00057

This article was submitted to Marine Pollution, a section of the journal Frontiers in Marine Science.

Copyright (C) 2014 Soto, Botello, Licea-Durán, Lizárraga-Partida and YáñezArancibia. This is an open-access article distributed under the terms of the Creative Commons Attribution License (CC BY). The use, distribution or reproduction in other forums is permitted, provided the original author(s) or licensor are credited and that the original publication in this journal is cited, in accordance with accepted academic practice. No use, distribution or reproduction is permitted which does not comply with these terms. 